Maciej Grochowski

Instytut Języka Polskiego PAN, Kraków

magro@umk.pl
УДК 811.162.1'367.623

https://doi.org/10.18485/slavistika.2018.22.1.3

оригинални научни рад

примљено 22.02.2018

прихваћено за штампу 14.05.2018

\title{
PRZYMIOTNIKI JAKO WYKŁADNIKI NAWIĄZANIA W JĘZYKU POLSKIM
}

Artykuł omawia krytycznie relację syntaktyczno-semantyczną nazwaną przez Zenona Klemensiewicza „nawiązaniem” (1949). Autor uzasadnia hipotezę, że niektóre przymiotniki polskie reprezentujące poziom 'meta' mogą być wykładnikami tej relacji. Druga część artykułu zawiera opis syntaktyczny przymiotników poniższy, powyższy, niniejszy, rzeczony. Czwarta jednostka jest analizowana szczegółowo pod względem semantycznym.

Słowa klucze: semantyka, składnia, język polski, przymiotnik, referencja, metatekst, nawiązanie.

In the first part of the paper, syntactic and semantic relation called "nawiązanie" ('coherence') by Zenon Klemensiewicz in 1949, is critically discussed. The author argues the hypothesis that some Polish meta-level adjectives can be exponents of the relation in question. The second part of the paper synthetically describes the adjectives poniższy 'mentioned below', powyższy 'above-mentioned', niniejszy 'the following; herein', rzeczony 'the said'. This is analyzed in detail from a semantic point of view.

Keywords: semantics, syntax, Polish, adjective, reference, metatext, coherence

1. Pojęcie nawiązania jako stosunku syntaktycznego między zdaniami jest obecne w składni polskiej od co najmniej osiemdziesięciu lat. Wprowadził je do swojego aparatu terminologicznego Zenon Klemensiewicz (1937) i poddał szczegółowej charakterystyce (Klemensiewicz 1949, dalej cytuję za przedrukiem w wyborze: Klemensiewicz 1969), przeciwstawiając je pojęciu zespolenia i odnosząc to ostatnie do stosunku syntaktycznego w obrębie jednego zdania złożonego. Według Klemensiewicza (1969: 200-201) stosunek nawiązania (treściowy i/lub formalny) zachodzi na ogół w obrębie akapitu, nazywanego przez uczonego ustępem, a ściślej między dwoma członami wyróżnionymi za pomocą terminów podstawa nawiazania i człon nawiazany. Każdy człon ma postać zdania pojedynczego (lub jego równoważnika) albo zdania złożonego.

Ustęp jest tworem syntaktycznym, dla którego są charakterystyczne trzy jedności, mianowicie tematyczna, fonetyczna (ustęp jest usytuowany między dwiema dłuższymi pauzami) i syntaktyczna. Kryteria wyróżniania i opisu ustępu w ujęciu Klemensiewicza nie są dostatecznie klarowne, z drugiej strony, na co zwraca uwagę wielu badaczy (m. in. Karolak 1999, Wajszczuk 1981), analiza stosunku nawiązania nie wymaga odwoływania się do pojęcia ustępu ani do charakterystyki struktury ustępu. Jadwiga Wajszczuk (1981: 75) podkreśla wręcz, że wyodrębnianie akapitów jest nieprzydatne w analizie związków międzyzdaniowych. Według Stanisława Karolaka (1999: 639) kluczowym warunkiem zachodzenia stosunku nawiązania powinno być to, by podstawa nawiązania i człon nawiązany tworzyły spójną całość, nakładanie natomiast na argumenty tej relacji dodatkowych warunków strukturalnych (na przykład tego, że stosunek ten musi zachodzić między zdaniami) jest nieuzasadnione i niecelowe.

Klemensiewicz (1969: 202-203), charakteryzując formę stosunku nawiązania, wyróżnia trzy rodzaje wskaźników, gramatyczne, leksykalne i tematyczne. Wskaźniki 
Maciej Grochowski

te opisuje uczony, odwołując się do różnorodnej terminologii gramatycznej (części mowy i części zdania), a nawet leksykologicznej (np. stwierdzając, że między składnikami podstawy nawiązania i członu nawiązanego może zachodzić relacja synonimii). W drugiej części studium o nawiązaniu, z punktu widzenia metodologii składni istotniejszej, Klemensiewicz (1969: 204) określa stosunek członu nawiązanego do podstawy nawiązania, przeciwstawiając funkcję przyłączającą tego członu jego funkcji włączającej.

„Funkcja przyłączająca wyraża się tematycznym wskaźnikiem nawiązania.” (Klemensiewicz 1969: 204) Jest ona urzeczywistniana wtedy, gdy podstawa nawiązania $(\mathrm{PN})$ i człon nawiązany $(\mathrm{CN})$ są gramatycznie i semantycznie niezależne, lecz tworzą jedność treściową. Por. np. sekwencje dwuwypowiedzeniowe

(1) PN Pójdziesz na koncert? CN Nie wiem. (Klemensiewicz 1969: 204)

(2) PN Piotr prosit Annę, by wróciła do niego. CN Anna nie chciała wrócić do Piotra. (Karolak 1999: 548)

Człon nawiązany pełni funkcję włączającą wtedy, gdy nie jest gramatycznie i/lub semantycznie samowystarczalny, a jego treść staje się komunikatywna dopiero na tle podstawy nawiązania. Funkcja ta jest realizowana za pomocą gramatycznych i leksykalnych wskaźników nawiązania. Do wskaźników gramatycznych należą spójniki, zaimki anaforyczne, a także wyrazy pełniące inne funkcje w zdaniu; por. np. jego w (3), podobało się w (4). Przykładem wskaźnika leksykalnego jest wyraz mający znaczenie uzupełniające w stosunku do tego, co zostało wcześniej powiedziane, np. drugi w członie nawiązanym w (5), korespondujący z wyrazem starszy w podstawie nawiązania. Por.

(3) PN Zadawat pytania starszy z oficerów, porucznik. CN Jego ciemna twarz sportowca o rysach twardych i regularnych wyrażała chłód i pogardę. (Klemensiewicz 1969: 204)

(4) PN Dziewczyna zaśpiewała. CN Podobało się. (Klemensiewicz 1969: 205)

(5) PN Zadawat pytania starszy z oficerów, porucznik. CN Drugi oficer, płowy blondyn o wygladzie pruskiego junkra, wspartszy się szerokimi plecami o ścianę, obojętnie spoglądat przez ramię w okno. (Klemensiewicz 1969: 206)

Trafny przykład nawiązania włączającego podaje Karolak (1999: 548), referując i interpretując teorię Klemensiewicza, por.

(6) Piotr prosit Annę, aby wróciła do niego. Odmówita.

Teza Karolaka, iż ,włączenie polega tu na zastosowaniu wielokrotnej elipsy” z powodu niewypełnienia pozycji podmiotu, dopełnienia i przydawki dopełniającej, nie ma właściwego uzasadnienia w świetle mojej koncepcji elipsy (Grochowski 1978). Interpolowanie wyrażeń argumentowych o znanej wartości leksykalnej jest operacją techniczną, a nie merytoryczną; por. (6) z (7):

(7) Piotr prosił Annę, aby wróciła do niego. Anna odmówiła powrotu do Piotra.

Jak pokazują to cytowane dotychczas przykłady, stosunek nawiązania - bez względu na przyjęte przez Klemensiewicza kryteria opisu, a więc formę i funkcję członów tej relacji - polega na identyczności semantycznej i/lub referencyjnej komponentów podstawy nawiązania i członu nawiązanego (Karolak 1999: 639). Ta zależność niewątpliwie łączy porównywane obiekty, przeciwstawianie natomiast gramatycznych 
i leksykalnych wskaźników nawiązania, a tym bardziej obu tych typów wskaźnikom tematycznym, jest dyskusyjne. Nie ma bowiem jednostek leksykalnych pozbawionych właściwości gramatycznych ani właściwości gramatycznych, które nie odnosiłyby się do jednostek leksykalnych, ich klas bądź połączeń jednostek. Wskaźniki tematyczne muszą więc mieć postać jednostek lub ich połączeń.

Liczni badacze odwołując się do teorii Zenona Klemensiewicza, interpretowali relację nawiązania i poddawali jej opis krytycznej ocenie (por. m.in. Wajszczuk 1980, 1981, Karolak 1987, 1999, Walusiak 1999, Szkudlarek 2003). Biorąc pod uwagę dwie opozycyjne funkcje członu nawiązanego w stosunku do podstawy nawiązania, przyłączającą i włączającą, przeciwstawiano nawiązanie treściowe formalnemu. Funkcję włączającą spełniają gramatyczne i leksykalne wskaźniki nawiązania. Jadwiga Wajszczuk (1981: 77-81) zakwestionowała opozycję przyłączania i włączania, uznając ją za metaforyczne rozróżnienie „niewyrażonych i wyrażonych związków międzyzdaniowych”. Zaproponowała zawężenie zakresu pojęcia nawiązania do stosunku między obiektami sekwencji dwuzdaniowych, uznając, że współcześnie nawiązaniami międzyzdaniowymi nazywa się ,spójniki międzyzdaniowe i zaimki anaforyczne o zasięgu przekraczającym granicę zdania, do którego należą" (Wajszczuk 1981: 83).

2. Badacze relacji nawiązania koncentrowali uwagę na jej wykładnikach formalnych, przyjmując, że należą one do klasy zaimków (anaforycznych i kataforycznych) i spójników. W nowszej literaturze niektóre wykładniki nawiązania zalicza się również do relatorów i partykuł (Kisiel 2012, Grochowski, Kisiel, Żabowska 2012, 2014), np. dodających (co więcej, mało tego, poza tym) czy rozszerzających (nawiasem mówiac, swoja droga). O ile mi wiadomo, nie zwracano uwagi na to, że leksykalnymi wykładnikami nawiązania mogą być także niektóre przymiotniki.

Najogólniejsza przesłanka, przyjęta w tym artykule, jest taka, że przymiotniki nawiązujące mogą odsyłać zarówno do wspólnej wiedzy interlokutorów (por. np. wiadomy, znany, odnośny), jak i do tego, co się aktualnie mówi (np. niniejszy) bądź do tego, co zostało albo zostanie powiedziane (np. wspomniany, wymieniony, rzeczony, powyższy, poniższy, następujący). Por. np.

(8) Ale czym wobec tego pan się kieruje, czym uzasadnia pan swoje własne postępowanie w wiadomej sprawie? (NKJP)

(9) Zwykle działo się to wedtug znanego schematu: ktoś go zaatakowat, powiedziat - my wiemy, że ty masz to i tamto na sumieniu, i facet (...) dochodzit do wniosku, że należy wystapić z samokrytyka. (NKJP)

(10) A gdzie jest w tej sprawie odnośne pismo z okragła pieczatka zaopatrzone tamtejszym numerem przeciagniętym przez tutejszy dziennik podawczy? (NKJP)

(11) Opracowanie niniejsze powstało pierwotnie jako skrypt dla studentów fizyki. (NKJP)

(12) W sytuacji, gdy odbiorca produktów lub ustug firmy jest podatnik podatku od towarów i ustug, firmie przystuguje prawo do odliczania wspomnianego wyżej podatku. (NKJP)

(13) Wymieniony resort pozostała część dotacji przeznacza na potrzeby jednostek przemystu obronnego. (NKJP)

Славистика XXII/1 (2018) 
(14) Szparko udat się, pomrukujac gniewnie, do zamkowej kuchni, gdzie kazat podać sobie wszystko, czym rzeczona kuchnia dysponowała. (NKJP)

(15) Po napisaniu powyższego tekstu otrzymałem dwa kolejne listy, chloszczace mnie. (NKJP)

(16) Właścicielem gabinetu, a zarazem autorem poniższego artykułu jest młody pracownik naukowy Akademii Medycznej. (NKJP)

(17) Uważam, że w naukach mistrzów zen możemy wyróżnić następujace rodzaje znaków: bezpośrednie znaki paradoksowe, pośrednie znaki paradoksowe i znaki nieparadoksowe (formalne). (NKJP)

A zatem przymiotniki nawiązujące spełniają obie funkcje członu nawiązanego (w rozumieniu Klemensiewicza), przyłączającą i włączającą. Natomiast podział przymiotników według kryterium tych funkcji, a także podział na rodzaje wykładników stosunku nawiązania, uważam - w myśl krytycznej oceny koncepcji Klemensiewicza, wyrażonej przez jego kontynuatorów i przedstawionej już wyżej - za nieuzasadniony.

Przymiotniki nawiązujące do tego, co zostało, jest lub będzie powiedziane, należą do licznej klasy jednostek o funkcji intratekstualnej. Nie komunikują one o właściwościach przedmiotów ani o relacjach między przedmiotami, tak więc są bezdyskusyjnymi przymiotnikami przede wszystkim w świetle kryteriów morfologicznych (Saloni 1974, Saloni, Świdziński 1998). Z punktu widzenia semantyki i składni reprezentują nieprzedmiotowy poziom języka, inaczej mówiąc poziom meta (Danielewiczowa 2007). Świadomie nie chcę uściślać przynależności przymiotników nawiązujących do wielowarstwowego poziomu meta, nie jest on bowiem w dostatecznym stopniu zbadany. Warto jednak zwrócić uwagę, że intratekstualność może być cechą systemową danej jednostki (lub jednej z jednostek homonimicznych, por. pozostały w (18) w porównaniu z (19)), niezależną od jej użycia, albo cechą ujawniającą się tylko w określonych użyciach jednostki, por. np. inny w kontekście nawiązującym (20) i nienawiązującym (21):

(18) Jedna z kobiet, jasnowłosa, leżała nieruchomo, natomiast dwie pozostate ciemnowłosa i ruda - wykonywaty szereg czynności. (NKJP)

(19) Pracownicy, która urodziła więcej niż jedno dziecko przy jednym porodzie, przystuguje urlop macierzyński w wymiarze stosownym do liczby dzieci pozostałych przy życiu. (NKJP)

(20) Babka klęczała w tawce blisko ottarza. Trzy inne kobiety tkwity daleko od siebie, nieruchome i osamotnione jak porzucone figury. (NKJP)

(21) Jedynie milczenie oznacza najczystsza powściagliwość w stosunku do innego czlowieka, którego nie chce się zagluszyć dźwiękami własnej mowy. (NKJP)

$\mathrm{Na}$ osobliwe właściwości niektórych przymiotników o funkcji intratekstualnej zwraca się uwagę od blisko pół wieku (Wierzbicka 1969, 1971), literatura składniowo-semantyczna poświęcona poszczególnym jednostkom jest coraz bogatsza; por. np. o istny w: Danielewiczowa 2011, Grochowski 2009, o kolejny, następny, poszczególny, wszelki w: Grochowski 2000, 2003, 2016, o niniejszy, poniższy, powyższy, pozostaty w: Salińska 2006, 2007, o zwyczajny, zwykty w: Maryn 2009, Danielewiczowa 2012. Mimo to brak jest prac dotyczących globalnej charakterystyki klasy. 
3. W dalszej części tego artykułu omówię krótko przymiotniki nawiązujące niniejszy, poniższy, powyższy, rozwijając niektóre wątki wstępnej (jedynej, którą znam) propozycji na ten temat, autorstwa Doroty Salińskiej (2007), która z przyczyn pozamerytorycznych przestała badać te przymiotniki. W ostatniej części artykułu zajmę się analizą przymiotnika rzeczony, którego prawdopodobnie nikt dotychczas nie rozważał (jest jedynie podany w aneksie do artykułu Danielewiczowej (2007) o metaprzymiotnikach).

Przymiotniki nawiązujące, typowe jednostki poziomu meta, są apredykatywne i arematyczne. Występują w pozycji syntaktycznej atrybutów rzeczownika (zarówno w antepozycji, jak i w postpozycji względem niego), co zgodnie z tezą Jerzego Kuryłowicza (1987: 205) o prymarności funkcji atrybutywnej przymiotnika (i sekundarności funkcji predykatywnej) pozwala bezdyskusyjnie zaliczyć je do tej klasy. Próba zmiany tej pozycji na orzecznikową powoduje dewiację; por. np.

(22) Rozporzadzenie niniejsze wchodzi w życie z dniem ogłoszenia. (NKJP)

(23) *Rozporządzenie, które jest niniejsze, wchodzi w życie z dniem ogłoszenia.

(24) Wzrost wydobycia węgla ilustruje poniższa tabela. (NKJP)

(25) *Wzrost wydobycia węgla ilustruje tabela, która jest poniższa.

O arematyczności omawianych przymiotników świadczy to, iż nie mogą być one akcentowane niekontrastywnie i nie podlegają negacji w sposób niecytacyjny (Bogusławski 1977a, 1999). Akcent kontrastywny może padać, jak wiadomo, na dowolną sylabę, zanegować z kolei da się również wyrażenie przytoczone, ale wyniki takich operacji nie są diagnostyczne.

Badane przymiotniki nawiązujące mają ograniczoną łączliwość leksykalno-semantyczną. Przede wszystkim nie dopuszczają kookurencji z operatorami referencji (termin użyty zgodnie z: Topolińska 1984: 368), połączenia z wykładnikami wyznaczoności powodują powstanie pleonazmu, a z wykładnikami niewyznaczoności prowadzą do sprzeczności. Por. np. połączenia dewiacyjne z jednostkami ten, jakiś:

(26) *Z tej powyższej zależności wynikaja dwie istotne obserwacje.

(27) *Jakaś powyższa opowieść podpisuję swoim imieniem i nazwiskiem.

(28) *Tę poniższa trase polecam turystom zmotoryzowanym.

(29) *Rozstrzygnij, czy jakieś poniższe wypowiedzi sa zdaniami prostymi czy złożonymi.

(30) *Z ich inicjatywy ta / jakaś niniejsza praca ma szansę trafić do rąk każdego.

Nie przyłączają żadnych operatorów metapredykatywnych (jednostek typu bardzo, dosyć, sporo, trochę, niespetna, prawie, iście) ze względu na brak zgodnych z nimi cech semantycznych. Jak zapewne wszystkie przymiotniki reprezentujące poziom meta są niestopniowalne.

4. Podstawą analizy przymiotnika rzeczony są słowniki języka polskiego oraz NKJP (frekwencja w pełnym korpusie rzeczon* - 6287, rzeczen* (dla nom pl, r. męskoosobowy) - 716 [18.02.2018]). Definicje w słownikach oparte są na wyliczeniu bliskoznaczników (SJPD, SJPSz, USJP, SWJPDun), jedynie w ISJP i w WSJP mają charakter opisowy; definicja w ISJP jest metajęzykowa, w WSJP przedmiotowa (terminy stosowane w teorii definicji; por. np. Grochowski 1993). Według Borysia (2005: 532): od XV w. rzeczony 'wspomniany, wymieniony' [od rzec]. 
Przymiotnik rzeczony (ksiażk.) 'ten, o którym była mowa we wcześniejszej części wypowiedzi’ (WSJP) jest atrybutem rzeczownika w grupie nominalnej, ma zmienny szyk (neutralna jest antepozycja), nie występuje w pozycji predykatywnej, jest arematyczny (nie podlega akcentowaniu niekontrastywnemu ani negacji), nie przyłącza operatorów metapredykatywnych (jednostek typu bardzo, dosyć, prawie, zbyt), nie podlega stopniowaniu. Funkcjonalnie omawiany przymiotnik jest analogonem zaimka anaforycznego, kookurencja rzeczony z zaimkami wskazującymi (np. *ten rzeczony) powoduje powstanie pleonazmu, a z zaimkami nieokreślonymi (np. *jakiś rzeczony) - sprzeczności. Tę wstępną ocenę potwierdza NKJP: nie znalazłem w nim ani jednego przykładu połączenia formy rzeczony z zaimkiem wskazującym ani nieokreślonym. Badany przymiotnik jest komponentem wyłącznie konstrukcji składniowych, nie stanowi części wieloelementowych jednostek leksykalnych (związków frazeologicznych).

Liczne cechy przymiotnika rzeczony, wspólne z właściwościami omawianych w skrócie wyrazów niniejszy, poniższy, powyższy, potwierdzają tezę, że należy on do klasy jednostek reprezentujących poziom meta. W ostatniej części artykułu przedstawię pewne charakterystyczne konteksty użycia wyrazu rzeczony, świadczące o tym, że jest on wykładnikiem relacji nawiązania.

Grupa nominalna $\mathrm{z}$ atrybutem rzeczony jest rodzajem deskrypcji dyskursywnej (zgodnie z rozumieniem tego terminu wprowadzonym w pracy Bogusławski 1977b: 49). A zatem nie może on wystąpić w pierwszym linearnie wypowiedzeniu danej sekwencji, a w każdym razie na jego początku. Por. nieakceptowalne (bo oderwane od poprzedzającego kontekstu) wypowiedzenie (31) i akceptowalne w kontekście wypowiedzenie (32):

(31) *Wnet rzeczona dwójka nawiazuje kontakt głosowy z uwięzionym w skałach. (NKJP)

(32) J. Gasienica Roj wyrusza (...) kolejka na Kasprowy Wierch. Stamtad wysyta „szybka dwójkę”, Wojciecha Mateję i J. Tybora, a sam z reszta drużyny idzie ich śladem. Wnet rzeczona dwójka nawiązuje kontakt głosowy z uwięzionym w skałach. (NKJP)

Przymiotnik rzeczony kookuruje z rzeczownikiem, na ogół z nazwą pospolitą, zdecydowanie rzadziej z nazwą własną, użytym już we wcześniejszym kontekście; w wypadku kookurencji z nazwą własną koreferencja ma podwójny wykładnik. Por. np. (33), (34), (35), (36).

(33) TVN pokazała film, na którym widać, jak prezydencki minister X gładzi po kostiumie tlumaczkę z hiszpańskiego. Minister tlumaczyt, że film fatszuje rzeczywistość, bo jego ręka byta caty czas oddalona od rzeczonego kostiumu równo o 10 cm. (NKJP)

(34) Na środku wyśnionej rzeki, tego wymarzonego eldorado, stat sobie bezczelnie zwykty, chtopski wóz konny. Koń przygladał mi się z wyraźna drwina, a chtop ze stoickim spokojem ładowat szufla piach z dna rzeki na rzeczony wóz. (NKJP)

(35) Oto w pewnym sierocińcu pracuje wychowawca Stasiuk, a plochliwa wychowanka z najstarszej grupy dziewczą zwie się Manuela. I chociaż w przypadku rzeczonego Stasiuka nie pada jego imię, a w przypadku Manueli nazwisko, to oczywiste jest, że odnajdziemy w nich autorów ,Białego kruka” i ,, Kabaretu metafizycznego”. (NKJP) 
(36) Jestem bardzo szczęśliwy, że wychowałem się w PRL, ale jednocześnie bardzo zadowolony, że rzeczony PRL trafit szlag miesiac po mojej maturze. (NKJP)

Badany przymiotnik kookuruje ponadto z rzeczownikiem będącym quasi-synonimem bądź hiperonimem użytego wcześniej rzeczownika albo jego derywatu, przy czym porównywane rzeczowniki są koreferencyjne. Por. np. minispódniczka i kusa szmatka w (37) oraz krokodyli (krokodyl) i gad, a także zwierzak w (38):

(37) Nie było watpliwości. Minispódniczka stanowiła gustowne uzupetnienie kobiety posiadającej poza rzeczona kusa szmatka aparat fotograficzny i biały uśmiech. (NKJP)

(38) Bardzo poczciwa pani nawołujac do bojkotu torebek z krokodylej skóry żywi na pewno niektamana litość do gada. Nie dociera jednak do jej świadomości, że ktoś zdechnie z głodu, jeżeli rzeczonego zwierzaka nie ukatrupi, a na jego skórę nie znajdzie nabywcy. (NKJP)

Przymiotnik rzeczony może też współwystępować z rzeczownikiem pospolitym, implikowanym semantycznie przez użytą wcześniej nazwę własną, jak w (39), albo z rzeczownikiem, przyporządkowanym tej nazwie własnej na podstawie (wspólnej) wiedzy interlokutorów o świecie, jak w (40). Np. w (39) rzeczownik instytucja jest implikowany przez nazwę ZUS (Zakład Ubezpieczeń Społecznych), a w (40) rzeczownik dziennikarka może być przez niemałą liczbę użytkowników polszczyzny odniesiony do Moniki Olejnik. A więc w obu kontekstach zestawiane jednostki są koreferencyjne. Por.

(39) Maj to miesiąc, w którym fundusze otrzymaty od ZUS-u blisko $800 \mathrm{mln}$ zł należnych im składek - najwięcej, od kiedy rzeczona instytucja zaczęta przysyłać pieniądze na konta członków OFE. (NKJP)

(40) Monika Olejnik, komentujac Pana przestuchanie przed KS, powiedziała, że sprawiat Pan wrażenie jedynej osoby, która nikogo i niczego się nie boi, i nie jest z nikim powiazana. Przyznam, że (...) miałem podobne wrażenia co rzeczona dziennikarka. (NKJP)

Badany przymiotnik może nawiązywać do treści komunikowanej wcześniej przez zdanie albo sekwencję zdań, jak np. w (41), (42). Nie jest wykluczona substantywizacja omawianej jednostki przymiotnikowej, jak np. w (43). Por.

(41) Nigdy nie rozpytywat wprost o moje życiowe plany. I bardzo dobrze. Klnę się na Boga żywego - osobiście nie mam jeszcze nic do powiedzenia na rzeczony temat. (NKJP)

(42) Rzeczywiście, historia nie zna podobnego przypadku erupcji pomysłów kompozytorsko-aranżacyjnych $w$ dziedzinie muzyki popularnej. Żeby jednak cokolwiek sensownego w rzeczonej kwestii powiedzieć, należy cofnać się do późnych lat 50. (NKJP)

(43) Zatem on, wicegubernator, uważa, reasumując swój krótki pobyt na Wyspach, że należy: po pierwsze, zlikwidować samorzad terytorialny, po drugie, wywieźć stąd lu$d z i$, zwłaszcza niepotrzebnych, bo utrzymanie ich jest trzy razy droższe niż na stałym ladzie, i po trzecie, pozostatym dać pozwolenie na odstrzat przelotnych ptaków i na wyrąb lasu na opat, ochrona przyrody bowiem nie ma sensu tam, gdzie ludzie z głodu umieraja. Tutaj wicegubernator zamilkt, dajac czas, by rzeczone dotarto do narodu. (NKJP) 
Charakterystyczną cechą pragmatyczną rozważanego przymiotnika, wspólną także dla jednostek niniejszy, powyższy, poniższy, jest jego przynależność do warstwy tzw. słownictwa książkowego (na co zwracają uwagę wszystkie słowniki współczesnej polszczyzny, choć stosują różną terminologię).

\section{Literatura cytowana}

Bogusławski, Andrzej. Problems of the thematic-rhematic structure of sentences. Warszawa: PWN, 1977a.

Bogusławski, Andrzej. „O interpretacji zdań z wyrażeniami okazjonalnymi”. Przegląd Humanistyczny 2, 1977b: 39-56.

Bogusławski, Andrzej. “Inherently Thematic or Rhematic Units of Language”. [W:] E. Hajičová, T. Hoskovec, O. Leška, P. Sgall, Z. Skoumalová (red.) Travaux du Cercle Linguistique de Prague 3. Amsterdam: Benjamins, 1999, 211-224.

Boryś, Wiesław. Słownik etymologiczny języka polskiego. Kraków: Wydawnictwo Literackie, 2005.

Danielewiczowa, Magdalena. „Przymiotniki nieprzymiotniki (O pewnym niezwykłym typie wyrażeń w języku polskim)”. Zbornik Matice srpske za slavistiku 71-72, 2007: 223-235.

Danielewiczowa, Magdalena. „Iście raz jeszcze”. Prace Filologiczne 60, 2011: 61-72.

Danielewiczowa, Magdalena. „Nazywając rzeczy po imieniu: o znaczeniu wyrażeń zwyczajnie / najzwyczajniej". [w:] H. Burkhardt, R. Hammel, M. Łaziński (red.) Sprache im Kulturkontext. Festschrift für Alicja Nagórko. Frankfurt/M: Peter Lang, 2012, 25-36.

Grochowski, Maciej. „Czy zjawisko elipsy istnieje?” [W:] M. R. Mayenowa (red.) Tekst. Język. Poetyka. Wrocław: Ossolineum, 1978, 73-85.

Grochowski, Maciej. Konwencje semantyczne a definiowanie wyrażeń językowych. Warszawa: Biblioteka Myśli Semiotycznej, 1993.

Grochowski, Maciej. „Funkcja intratekstualna leksemów a ich cechy gramatyczne. Analiza wyrażenia wszelki”. Poradnik Językowy 2000, 5: 1-8.

Grochowski, Maciej. „O znaczeniach przymiotników metatekstowych następny, kolejny”. [W:] M. Gębka-Wolak, I. Kaproń-Charzyńska, M. Urban (red.) Studia z gramatyki i leksykologii języka polskiego. Prace dedykowane Profesor Marii Szupryczyńskiej. Toruń: UMK, 2003, 196-205.

Grochowski, Maciej. „O cechach składniowych i łączliwości jednostek istny, iście”. Poradnik Językowy 2009, 1: 50-59.

Grochowski, Maciej. „Poszczególne wśród operatorów kwantyfikacji”. LingVaria 2016, 2 (22): 83-95.

Grochowski, Maciej, Anna, Kisiel, Magdalena Żabowska. „Granice jednostek języka a praktyka leksykograficzna". Polonica 32, 2012: 177-190.

Grochowski, Maciej, Anna, Kisiel, Magdalena Żabowska. Słownik gniazdowy partykuł polskich. Kraków: Polska Akademia Umiejętności, 2014.

ISJP: Inny słownik języka polskiego (red. Mirosław Bańko). T. 1-2. Warszawa: Wydawnictwo Naukowe PWN, 2000.

Karolak, Stanisław. „Pronominalne a niepronominalne wskaźniki nawiązania w tekście wielozdaniowym”. Прилози 12, 1987, 2: 87-102.

Karolak, Stanisław. „Spójność syntaktyczna (koherencja)”, „Wskaźniki nawiązania”. [W:] K. Polański (red.) Encyklopedia językoznawstwa ogólnego. Wrocław: Ossolineum, 1999: 638-639, 547-548.

Kisiel, Anna. „STR zdań z partykułami dodającymi”. Linguistica Copernicana 7, 2012: 139-151.

Klemensiewicz, Zenon. Składnia opisowa współczesnej polszczyzny kulturalnej. Kraków: Polska Akademia Umiejętności, 1937.

Klemensiewicz, Zenon. „O syntaktycznym stosunku nawiązania”. Slavia 19/1-2, 1949: 13-27.

Klemensiewicz, Zenon. Ze studiów nad językiem i stylem. Warszawa: PWN, 1969.

Kuryłowicz, Jerzy. Studia językoznawcze. Warszawa: PWN, 1987.

Maryn, Dagmara. „O znaczeniach przedmiotowych i metatekstowych przymiotników zwykty i zwy-

Славистика XXII/1 (2018) 
czajny”. [W:] B. Milewska, S. Rzedzicka (red.) Wokół słów i znaczeń III. Z zagadnień semantyczno-leksykalnych. Gdańsk: UG, 2009: 293-300.

NKJP: Narodowy korpus języka polskiego [on-line]. www.nkjp.pl [18.02.2018]

Salińska, Dorota. „Jednostka metatekstowa pozostaty”. AUNC. Filologia Polska 62, 2006: 161-168.

Salińska, Dorota. „Cechy składniowe i semantyczne przymiotników o funkcji intratekstualnej (niniejszy, powyższy, poniższy)”. [W:] A. Dobaczewski (red.) Studia nad współczesną polszczyzną. Gramatyka, semantyka, pragmatyka. Toruń: UMK, 2007, 145-151.

Saloni, Zygmunt. „Klasyfikacja gramatyczna leksemów polskich”. Język Polski 54/1-2, 1974 : 3-13, 93-101.

Saloni, Zygmunt, Marek Świdziński. Składnia współczesnego języka polskiego. Warszawa: Wydawnictwo Naukowe PWN, 1998.

SJPD: Słownik języka polskiego (red. Witold Doroszewski). T. 1-11. Warszawa: Wiedza Powszechna, PWN, 1958-1969.

SJPSz: Słownik języka polskiego (red. Mieczysław Szymczak). T.1-3. Warszawa: PWN, 1978-1981.

SWJPDun: Słownik współczesnego języka polskiego (red. Bogusław Dunaj). Warszawa: Wilga, 1996.

Szkudlarek, Ewa. Wskaźniki nawiązania we współczesnych tekstach polskich (Na materiale współczesnej nowelistyki polskiej). Łódź: UŁ, 2003.

Topolińska, Zuzanna. „Składnia grupy imiennej”. [W:] Z. Topolińska (red.) Gramatyka współczesnego języka polskiego. Składnia. Warszawa: PWN, 1984, 301-389.

USJP: Uniwersalny słownik języka polskiego (red. Stanisław Dubisz). T. 1-4. Warszawa: Wydawnictwo Naukowe PWN, 2003.

Wajszczuk, Jadwiga. „Substytucyjna i metatekstowa interpretacja zjawiska anafory”. Јужнословенски филолог 36, 1980: 121-151.

Wajszczuk, Jadwiga. „Pojęcie nawiązania. Analiza koncepcji Zenona Klemensiewicza”. Polonica 7 , 1981: 67-83

Wajszczuk, Jadwiga. O metatekście. Warszawa: KLF UW, 2005.

Walusiak, Ewa. Hierarchizacja treści i nawiązanie wewnątrztekstowe. Wykładniki leksykalne. Warszawa: Energeia, 1999.

Wierzbicka, Anna. Dociekania semantyczne. Wrocław: Ossolineum, 1969.

Wierzbicka, Anna. „Metatekst w tekście”. [W:] M. R. Mayenowa (red.) O spójności tekstu. Wrocław: Ossolineum, 1971, 105-121.

WSJP: Wielki słownik języka polskiego PAN (red. Piotr Żmigrodzki). Instytut Języka Polskiego PAN, Kraków 2007< http://www.wsjp.pl/> 18.02.2018.

\section{Маћеј Гроховски}

\section{ПРИДЕВИ КАО ЕКСПОНЕНТИ НАДОВЕЗИВАЬА У ПОљСКОМ ЈЕЗИКУ}

\section{Резиме}

У првом делу чланка обрађује се синтаксично-семантички однос који је Зенон Клеменсјевич (1949) назвао „надовезивањем”. Пољски синтаксичар издвојио је две функције које надовезани члан врши у односу на основ надовезивања - функцију прикључивања и функцију укључивања. Ове су функције биле предмет критике у синтаксичкој литератури. Сматрало се, наиме, да споменути однос увек има своје формалне експоненте. У њих се убрајају везници, анафорске и катафоричке заменице, речце.

Аутор је у чланку поставио и потврдио нову тезу, а то је да лексички експоненти надовезивања могу бити и поједини придеви који представљају мета ниво. Они указују на 
заједничко знање интерлокутора (нпр. wiadomy, znany, odnośny) у вези са оним о чему се тренутно говори (нпр. niniejszy) или на оно што је речено, односно оно што ће бити речено (нпр. wspomniany, wymieniony, powyższy, poniższy, rzeczony).

Други део чланка садржи синтаксички опис четири надовезујућа придева: niniejszy, powyższy, poniższy, rzeczony. Детаљној семантичкој анализи подвргнут је последњи међу наведеним придевима, који није досад проучаван. Придев rzeczony 'поменути' је апредикативан и арематски, не прикључује метапредикативне операторе, не подлеже степеновању. Јавља се искључиво у номиналној фрази, а функционално је аналогон анафорској заменици.

Кључне речи: семантика, синтакса, пољски језик, придев, референција, метатекст, надовезивање. 